\title{
Being Moved
}

\section{Andrew Douglas}

A man is a passing mood coming and going in the mind of his country; he is the twitching of a nerve, a smile, a frown, a thought of shame or honour, as it may happen.

Samuel Butler

For Samuel Butler, as he wrote in his Notebooks (1917), humanity is an ultimately unknowable substance, but one in whom feelings are foremost and sensed according to transitioning motion: "he [humankind] is a substance in a statical or dynamical condition and feeling the passage from one state into another" (1917:78-79). Writing in the era of transport steam and in the wake of the emerging science of thermodynamics, no less than Darwinism, Butler might well be expected to have seen the world through the lens of mobility and redeployments of energy and matter. Yet his attentiveness points to a greater prescience. His was a world no less imagined according to non-equilibrium transactions (machines evolving according to natural selection and closed worlds coopted by global mercantile forces), a world that breaks with, and opens beyond, what Michel Foucault described as the old disciplinary "enclosures of civil society" - "schools, manufactories, armies, etc." (1991: 103) - and which in Butler's case included an explicitly personal paternalism of the church and English civil society in general.

Where Butler parodically rebuked Darwin for an overly mechanistic evolutionism, suggesting he had taken "the life out of biology" (1923-26), Michel Foucault in turn recognised an eighteenth-century shift in governmentality that precisely sought to take hold of life. Augmenting existing familial models of sovereignty, a bio-political instrumentality was increasingly fitted to modes of life, measuring and modifying the affective behaviours and corporeal capacities of populations. Inherently nebulous, the "problem of populations" (1991: 99), and the political economies spawned by it, can be imagined to have bypassed individual perspectives and interests in favour of governing control indexed to tendencies and movements indicated by large numbers of persons.

If one consequence of this shift in governmentality was a disjunction between society and the individuals comprising it, Norbert Elias was drawn to investigate how societal bodies might be understood, on one hand as more than simply a large aggregation of individuals, and on the other, as distinct entities with contrary psychologies. Rejecting the notion of a founding social contract entered into by autonomous individuals in pursuit of collective benevolence, Elias recognised in societies themselves a "tissue of mobile relationships" and dependencies that might explain an evolving historical patterning of individuation (2001: 23). This "invisible order" in fact configures, as he noted, precisely engineered "types of individuality", and in the case of the modern West, one defined by minutely calibrated interdependencies calling for high levels of "psychical control" and affect management, but also a characterising sense of self autonomy and independence from others (2001: 1432). In such an individual, affect appears as both acutely one's own, but also, seemingly frustrated by societal forces.

Gernot Böhme, building on Elias' investigation of the civilising process historically, noted how in twentieth-century modernity, the self-constraint attributed to civilising interdependency is in fact overlaid by returning forms of "external constraint" and control - particularly "technical constraint" (2012: 4-5; emphasis in original). The consequence of this escalating technification is both a reduction in ethical (self-)constraint and a growing dependence on "technical norms", rather than moral ones. Hence "technological civilisation" builds in modernity towards an affective conflict, for on one hand, such a civilisation is predicated on a "decidedly unemotional stance", and on the other, it fosters the "development of an enormous imaginary domain" nurturing an otherwise truncated emotionality (2012: 27; emphasis in original). A shift towards technological norms opens the way for affectively 
geared and mediated environments where a "relaxation of intra-psychical constraint" also potentiates a manipulable subjectivity released from the ideal of subjective integrity and closure along with new technologies of societal control (2012: 26-27, 223).

What these particular facets make imaginable are how affective registers become inherent to consolidating powers and modes of governance. While for Raymond Williams (2001), the importance of subtle structures of feeling for understanding of cultural complexity and social agency were evident more than 50 years ago, an "affective turn", as it has more recently been termed (Clough \& Halley 2007), makes manifest their blunt pervasiveness. As Brian Massumi wrote, in media-saturated society media no longer mediates per se; it shuttles and amplifies affective or "empathy-based" responses directly between political and everyday domains in a feedback that obscures "moral reasoning and critical thinking" (1998: 44). Legitimation of governance comes to rest on felt responses collectively coordinated and orchestrated in accordance with a certain gratuitous mediation - for which the "circulation of violence-legitimating affect" is key (1998: 45). Where the disciplinary enclosures referred to previously bind a constituent body of persons within places defined by prescriptive routines and relations, affective legitimation presumes a less defined incorporation, favouring instead one drawn together empathetically and ambiently via spectacle and felt effects. So too is legitimation married to ever-expanding cycles of deterritorialised circulation of capital and reterritorialised surpluses drawn from commodification, though not without causing, as Massumi quoted Gilles Deleuze, a "crisis of enclosure" and the need to control or manage something like an open field of affects at once chaotic and productive (1998: 56-57). In what Deleuze (1992) referred to as societies of control, the task is to maintain hyper-mobility but within normatively recognisable - and therefore manageable and profitable - parameters, though even what counts as normative (a quality no longer antithetically paired with the 'abnormal') is rendered serially mutable (1998: 57).

If mutability then can be thought of as the very ground condition of capitalist societies of control, and our being together defined by modes of enclosure themselves contingent and variable, appeals (experientially, aesthetically or conceptually) to atmospheres - themselves indicative of a nebulous and contingently binding of things - carries a certain symptomatic valence. They are the carriers of affective traffic, and in turn, belonging through beholding. And indeed the scenographic underpinnings of this type of being together finds an early architectural precedent in Gottfried Semper who argued in 1860 that: "every artistic creation, every artistic pleasure, presumes a certain carnival spirit, or to express it in a modern way, the haze of carnival candles is the true atmosphere of art" (2004). As model for this "modern way", he may have had in mind an earlier participation in the design of exhibition stands for The Crystal Palace, erected in London's Hyde Park in 1851, a structure Mrs. (Mary Philadelphia) Merrifield famously described, in an essay titled "The harmony of colours", as being "the only building in the world in which atmosphere is perceptible" - the distant interior appearing "to be enveloped in a blue haze" (1851/1970: ii). Her point was that only the subtlety of an atmosphere could bind such a gigantean whole together without garishly conflicting with "the arrangement of colours on the walls" (1851/1970: ii). Certainly, the role of these exposition-type spaces, as Giorgio Agamben has argued, was to create "enchanted scene[s]", places where art and industry might merge and where a conversion of the use value of things to exchange value would approach something like an "epiphany of the unattainable" - an auratic hue today routinely infusing media and retail spaces alike (1993: 38).

Tracking an advance in atmospheric concern into contemporary contexts, Agamben's epiphany of the unattainable warrants comparison with what Jean Baudrillard, in the context of a sublimity found in exhibition show homes, has termed a "contemplation without hope", one that aligns interior design with the "general concept of ATMOSPHERE" (2002: 311; capitalisation in original). Here the modeling of interior 'ideals' sets in play varying generic, space-mobilising norms, norms that displace an older patriarchal-domestic symbolism staged as a "caesura between inside and outside" (2002: 309). In the modern domestic interior, as Baudrillard noted contrastively, there is an increasing lapse of harmony or stimmung between self, objects and the world of association they centre. The pockets of interiority that once stabilised these associations increasingly answer to an "unrestricted combinatorial" imperative, not closure nor subjective reflection, but an open field of linkages with no 
predefined syntax, propriety or taste. What a "sociology of interior design" reveals - as he imagined this new disciplinary enterprise - is not the tasteful signature of the bourgeois master of the familial crucible, but a new de-subjectified domain over which the occupying subject is both "actor and manager" (2002: 316). Becoming literally "an active engineer of atmospheres", space "is at his disposal like a kind of distribution system” (2002: 316). In such environments the rhetoric of 'personification' reigns - as Baudrillard parodied, "the atmosphere will be yours alone" - yet this appeal to agency arises precisely in contexts where the inverse predominates and where 'the interior', far from sheltering, makes up one of any number of modes of interiority geared to imparting invasive, affective states.

If for Mrs. Merrifield, the Crystal Place was atmospheric precisely because it "resembles the open air" (1851/1970: ii; emphasis added), the atmospheric engineering Baudrillard attributes to the 'new' interior design might be understood to respond to emerging modes of within-ness arising with the open field of a self-organising complex constituting control society. What Baudrillard recognised in the modern interior in the late 1960s were the effects of economic liberalism rapidly shedding its Keynesian, work and welfare consensus, one in which society more generally turns from object 'form' (with its interior/exterior dichotomies), and from a symbolic system indexed to the predetermination of the world (in fact the order of nature filtered anthropomorphically), towards a world increasingly defined instead by "practical computation and conceptualization on the basis of total abstraction" (2002: 317). Supplanting the older, given world, is its abstract antithesis, one needing to be "produced - mastered, manipulated, inventorised, controlled: a world, in short, that has to be constructed" (2002: 317; italicisation in original). "Man the interior designer" - an improbable entity to be elevated to the level of a new human type! - toils, not in or on interiors as such, but in the abstract field of mobile, affective surpluses engendered by the information and communications revolution. If for Massumi the societal aspect of control society is composed of three dimensions - firstly, a politi$\mathrm{cal} /$ governmental domain engineering command and control of life-affirming and life-diminishing forces, secondly, an economic domain indexed - in the name of "productivity and efficiency" - to monetary liberalism, and thirdly, a cultural domain of managed affects bridging the previous two dimensions - the new sociology Baudrillard anticipated might well be understood to entail reading into and across the constructed reality of the far from stable "self-organising system of systems" that is advanced capitalism (Massumi 1998: 47). Yet how might we conceive undertaking this task? As Böhme makes clear in the invited essay in this issue of Interstices, the insistent drive towards "the stage management of everything and anything" in contemporary society (spanning commodity aesthetics, politics, art and design practice, supermarkets and cities, no less than the self), points up the need for a "theory of atmospheres", one that can grasp what is critically at stake - the expanding scope of "affective participation in our world" (2014: 98).

Tonino Griffero, in a recent survey of phenomenological and ontological approaches to atmospheres - or what he defines as spatialised, objective feeling - offered a particular corrective to any fledgling "atmospherology" (2014: 101). If atmospheres persist as the in-between of objective and subjective states (as Böhme similarly asserts; 2014: 93), two errors must be avoided in grasping their significance: the first is a projectivistic explanation that recognises in atmospheres "nothing but inner feelings projected onto the outside" (2014: 103); the second, is an introjectionist error, that in fact underwrites the first by taking everything that was once attributed to external, pathic forces and redistributes them in the subject's inner, psychical domain. As Griffero rehearsed the well-known transformation of fifthcentury BC Greek culture, the introjectionist stance arises with a transition from an archaic sociality resting on mythical relations and a world saturated by imposing, magico-religious forces, toward one re-centred by an "anti-pathic" logos or reason (2014: 103). The reversal of mythos to logos - the tensions and risks of which were exemplarily tracked in the Oedipal tragedy - amounted, as Jean-Joseph Goux has argued, to the institution of a post-traditional, "anthropocenter[ed]" world, where human "auto-reflection" and "self-consciousness" become the new measure (1993: 119-120). It is a reversal that transfers inwardly - in a process Goux termed "deprojection" - all that the mythical world externalised and hence makes possible a long history of the soul and its subsequent double, the psyche. Outwardly the result is a knowing subject, as Goux put it, "with no master but himself" (1993: 160), 
and for whom the world is a thing to be remade precisely via an autodidactic virtuosity, yet inwardly is condensed all that once made up an external, cryptophoric (or monstrous/divine) domain that was managed culturally and collectively. Introjection and projection make up two sides of the same coin impressed precisely according to a long-exercised historical drive aiming to keep knowledge and $p a$ thos apart. The price, on one hand, is a society for whom “'progression', 'development,' or permanent 'innovation"' is imperative, and on the other, a subject fundamentally defined by psychical rupture and a synthesising will seeking an ameliorating abridgement with the world (Goux 1993: 204-205). Hence the dichotomy between civilising impulse and an affective proliferation recognised by Elias and Böhme, in Griffero is described this way:

A psychic self-referentiality that is not at all contradicted by today's media exhibitionism of one's intimate life, by an 'emotional capitalism' that supplants the public sphere, ignores the manipulated character of what it claims to be authenticity and transforms emotions, including the atmospheric ones, in 'entities to be evacuated, inspected, discussed, bargained, quantified and commodified', thus generating an emotional freeze that is not a corrective, but is the unexpected 'commercial' outcome of the introjectionist illusion. (2014: 106)

In a variety of ways, the essays gathered in this issue of Interstices grapple with, and contest, such an introjectionist illusion and the projectivistic capitalisation subsisting with it. If for Griffero, atmospheres are "quasi-things" (and "quasi-objective" for Böhme 2014: 94), it is because they are no more 'there for the taking' than they themselves totally possess their beholders; instead they facilitate an ebbing transferal always in excess of capitalisation (Griffero: 109 \& 149).

In this issue Michael Tawa considers a growing but imprecisely defined interest in the theme of atmosphere in architectural theory and practice, setting out the terms for conceiving an anatomy, inventory and codification of atmospheres. Perhaps not surprisingly, given the commentary above, in his appraisal Tawa aims to bypass the typical alignment of atmosphere with scenography and theatricality, seeking an affective spatiality in architecture's existential concrete presence, a presence spanning formal, geometric structures and spatio-temporal patterns. Laura McLauchlan and Sarah Treadwell tackle an altogether different engagement, one that maps the possible congruence between earthquakes and weather. The term "earthquake weather", as they note, has had a fluctuating history, both as as an observable phenomenon and a noted fiction. Exploring the ultimately inconclusive alignment of these terms, McLauchlan and Treadwell argue, by way of reportage and correspondence on the subject, for a certain space of delay or indetermination that resists "destroy[ing] an unknown through writing" (2014: 33) Paralleling their exercise of a less dominating account of terrestrial shifts, a series of images explore earthquake weather by articulating certain pauses in conglomerating matter. Anna Boswell, similarly concerned with incommensurate intersections - in this case cultural ones - utilises Jacques Rancière's concept of the "distribution of the sensible" and Sara Ahmed's notion of "angles of arrival" to consider the settler-colonial enterprise and incompatible structures of affect that incongruously underwrite settler-colonial place-making. Rethinking the synthesising presumption of atmospheres, she investigates an atmospherics of fracture specifically questioning the translatability of affect and atmosphere to indigenous worlds. By comparison, Carl Douglas thinks through a certain derailing of atmospheric stability, specifically the interruption of the smooth infrastructural governance of urban place by Auckland's kerbside collections of inorganic waste. What such collections bring into view, he argues, is the conditionality of public space, itself built on a certain administrative rationalism track-able to the nineteenth century. If the result is an urban hygienism that insistently expels waste from public sight, inorganic collections temporarily countermand this waste regime. Disrupting the policed order of the street for a short time, waste ceases to be a private matter, instead becoming something that affectively activates the otherwise tempered domain he terms "atmostechnics". Chris Cottrell, likewise working to exploit the limits of laminar smoothing - in this case a gallery setting rather than the street - advocates for turbulence as a productive, creative agent. Expanding on his installation work Cloud Sound (2012), undertaken at the Bundoora Homestead Art Centre in Victoria, Australia, he develops a critical commentary concerned with "thresholding" and the significance of an affective and atmospheric traffic established between the gallery and its suburban context. Working with the affective potential of interior space 
too, Mirjana Lozanovska examines the performative nature of a Byzantine church in Zavoj, Macedonia. Based on field notes taken there on the Day of the Holy Mother, an event celebrated annually on August 28, she considers the intertwining of ceremony, incense, song and prayer, geometry, volume, surface, iconography, and the movements of women's bodies. Faced with this atmospheric complex, she asks how architecture is moved beyond its material enterprise, and further, how the pleasure of observing, experiencing and describing such complexes are necessarily mediated by reading processes. Concluding the referred papers, Akari Kidd and Jan Smitheram pick up on a distinction Böhme makes in the invited section of this issue - that atmospheres are not only receptive entities; they can be produced (2014: 84). Specifically, Kidd and Smitheram explore how affect moves us and, specifically, how we can design affective environments rather than use affect as a tool for interpretation, analysis or description. Referencing a studio design project from the Victoria University of Wellington, School of Architecture, they examine discourses on affect and new materialism, developing in turn, design strategies they term "de-materialising, diagramming, and re-materialising".

What these papers collectively point to is the astonishing lability of affect and the mobility it exercises over setting and selves. Eve Kosofsky Sedgwick, reviewing the work of Silvan Tomkin on affect, made a pertinent observation relative to this question of shiftiness: if the predominant understanding across the last century of the introjectionist condition has focused on psychical drives, particularly sexuality as a driver (the Oedipal scenario being the reigning trope), affect has tended to be understood as a secondary 'colouration' of these primary 'instincts' - instincts Sedgwick identified as binary or on-off in the instrumental directness of their satisfaction (2003: 99-101). Conversely, given the plethora of configurations in which affect appears, it can be thought of by comparison as analogue in nature - in other words, "graduated and/or multiply differentiated" (2003: 101). Without object per se, affect amplifies and diminishes in fickle and roundabout ways and in fact, as Sedgwick argued, much of what Freud attributed to the $I d$ in terms of drives is closer to an analogue/affect system (2003: 21). Further, the drives themselves are better understood as responsive and even secondary to affective motivations. Psychically this would mean something like a double system - drive and affect, digital and analogue, driven control and ambiguity - constantly enfolding with itself. Perhaps not surprisingly, this systems analogy - itself a product of the development of cybernetic feedback or enfolding between the 1940s and 1960s (Sedgwick 2003: 105) - seems to closely mirror the systematicity of control societies that Deleuze diagnosed and the affective capitalism sustaining it. If disciplinary power moulded individuals in its determinant environments, the emerging potency of control societies is its "free-floating" subtlety, a subtlety that perpetually modulates modes of individuality rather than whole persons, producing, setting by setting, variously managed "dividuals" as Deleuze termed it (1992: 4-5). Acknowledging the confounding logic of this emerging power - a complexity allegorised as serpent-like - Deleuze concluded with a challenge to "young people": "It's up to them to discover what they are being asked to serve, just as their elders discovered, not without difficulty, the telos of the disciplines” (1992: 7). Nearly 25 years on, a theory of atmospheres, or as Griffero nominates it, an atmospherology, would seem to offer at least one avenue for grasping a projectivistic capitalisation of affect and the serial, generic norms it trades in. 


\section{References}

Agamben, G. (1993). Stanzas: Word and phantasm in western culture (R. Martinez, Trans.). Minneapolis, MN \& London, England: University of Minnesota Press.

Baudrillard, J. (2002). Structures of interior design [1968]. In B. Highmore (Ed.), The everyday life reader (pp. 308318). London, England \& New York, NY: Routledge.

Böhme, G. (2012). Invasive technification: Critical essays in the philosophy of technology (C. Shingleton, Trans.). London, England: Bloomsbury.

Böhme, G. (2014). The theory of atmospheres and its applications (A.-Chr. Engels-Schwarzpaul, Trans.). Interstices $15,92-99$.

Butler, S. \& Jones, H. (Eds.) (1917). The notebooks of Samuel Butler. New York, NY: E. P. Dutton \& Co. (reproduced by Cornell University Library, Digital Collections).

Butler, S., Jones, H. \& Bartholomew, A. T. (Eds.) (1923-26). Shrewsbury Editions of the works of Samuel Butler. New York, NY: Dutton.

Clough, P. \& Halley, J. (2007) (Eds.). The affective turn: Theorizing the social. Durham, NC \& London, England: Duke University Press.

Deleuze, G. (1992). Postscript on the societies of control. October, Vol. 59: 3-7.

Foucault, M. (1991). Governmentality. In, G. Burchell, C. Gordon, \& P. Miller, (Eds.). The Foucault effect: Studies in governmentality (pp. 87-104). Chicago, IL: The University of Chicago Press.

Elias, N. \& Schröter M. (Eds.), (2001). The society of individuals (E. Jephcott, Trans.). New York, NY \& London, England: Continuum.

Griffero, T. (2014). Atmospheres: Aesthetics of emotional space (S. De Sanctis, Trans.). Farnham, England \& Burlington, VT: Ashgate.

Goux, J. J. (1993). Oedipus, philosopher (C. Porter, Trans.). Stanford, CA: Stanford University Press.

Massumi, B. (1998). Requiem for our prospective dead: (Toward a participatory critique of capitalist power). In, E.

Kaufman \& K. Heller (Eds.). Deleuze and Guattari: New mappings in politics, philosophy, and culture. Minneapolis, MN \& London, England: University of Minnesota Press.

Merrifield, M. P. (1851/1970). Essay on the Harmony and Contrast of Colours. In, The Arts Journal Illustrated catalogue: The industry of nations, 1851 (i-viii). London, England: David \& Charles.

Sedgewick, E. K. (2003). Touching feeling: Affect, pedagogy, performativity. Durham, NC \& London, England: Duke University Press.

Semper, G. (2004). Style in the technical arts; Or, practical Aesthetics (H. F. Mallgrave \& M. Robinson, Trans.). Los Angeles, CA: Getty Research.

Williams, R. (2001). The long revolution. London, England: Vintage Books. 